\title{
An uncommon cause of portal hypertension
}

\author{
Francisco Almeida Cunha, ${ }^{1}$ Ana Luísa Silva, ${ }^{2}$ Maria Gabriel Jacob ${ }^{2}$
}

${ }^{1}$ Department of Internal Medicine, Centro Hospitalar São João, Oporto, Oporto, Portugal

${ }^{2}$ Centro Hospitalar São João, Oporto, Oporto, Portugal

\section{Correspondence to}

Dr Francisco Almeida Cunha francisco.pcunha@gmail.com

Accepted 3 September 2015

CrossMark

\section{To cite: Cunha FA,}

Silva AL, Jacob MG. BMJ

Case Rep Published online: [please include Day Month Year] doi:10.1136/bcr-2015212665

\section{DESCRIPTION}

A 68-year-old woman with no history of hepatic disease or risk factors, with a 2-month duration of an increasing waist circumference and watery diarrhoea, as well as peripheral oedema, presented to the emergency department. The initial diagnostic work up revealed a large volume, high-gradient ascites, with a marked dilation of the splanchnic veins on angio-CT (figure 1). She was admitted for study and had a rapidly declining clinical status, with an episode of massive variceal haemorrhage. Intrahepatic causes of portal hypertension were excluded. Colonoscopy revealed marked swelling of the mucosa, with no suspicious lesions. Multiple peritoneal fluid cytologies were consistently negative for malignancy. Echocardiogram excluded haemodynamic features of constrictive pericarditis. Doppler hepatic imaging revealed patency of the suprahepatic veins and hepatopetal blood flow.

Angiography of the inferior mesenteric artery revealed an arteriovenous malformation (AVM) with its middle and terminal branches attached to the inferior mesenteric vein, which was markedly dilated (figure 2). Embolisation of the AVM was performed after weighing the costs and benefits of a surgical procedure.

The ascites resolved in the course of a few days, with rapid improvement of the patient's clinical status, with no signs of mesenteric ischaemia. However, the patient eventually died due to methicillin-resistant Staphylococcus aureus septic

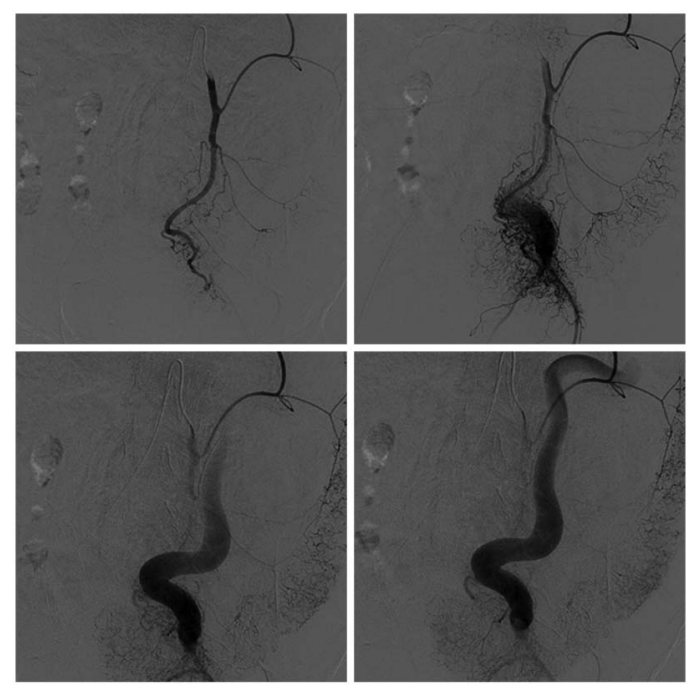

Figure 2 Sequential angiography frames depicting the complex network of aberrant communications between the inferior mesenteric artery and a markedly ectasiated and distorted inferior mesenteric vein.

shock related to an indwelling central venous catheter infection.

Although uncommon, arterioportal fistulae are a well-known cause of portal hypertension and ascites. ${ }^{1}$ Portal hypertension due to a mesenteric fistulae, however, is exceedingly rare, with sparse reporting in the literature. ${ }^{2}$
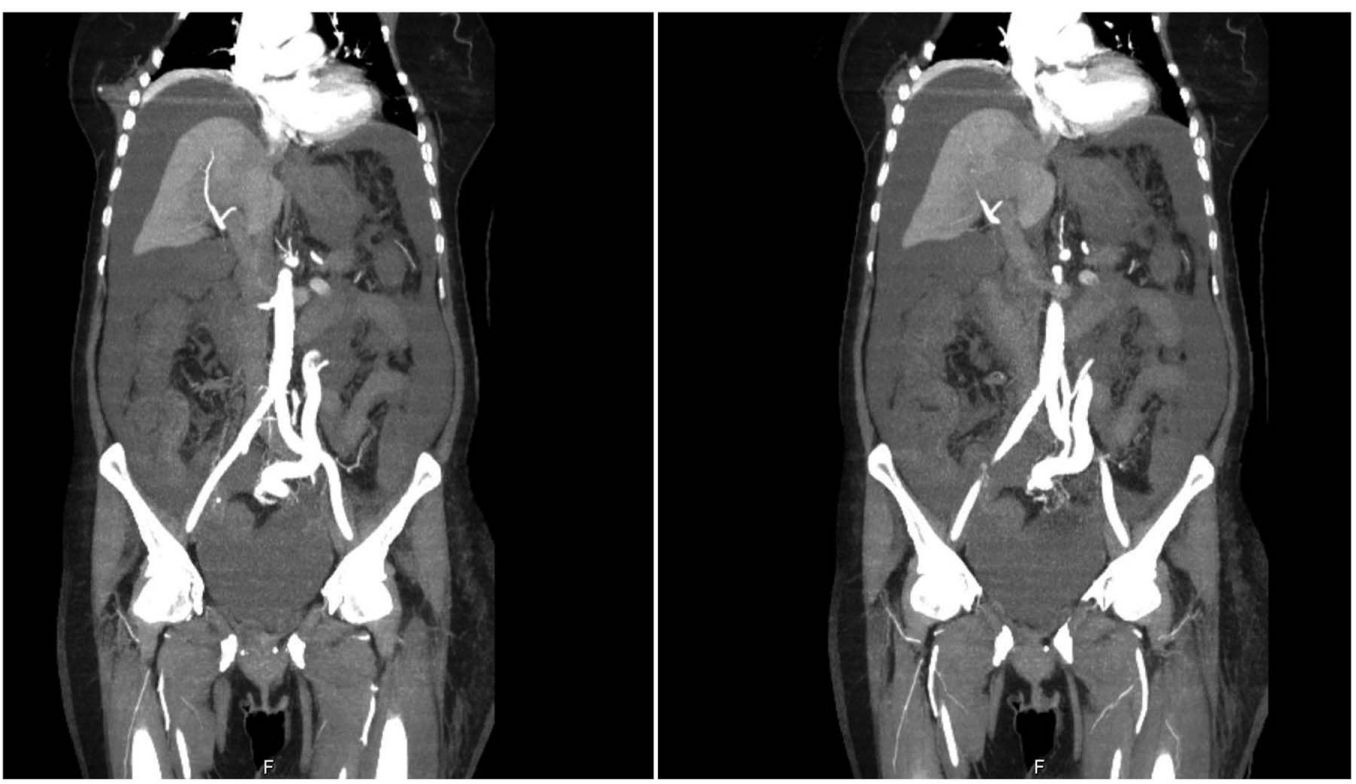

Figure 1 Abdominal angio-CT showing a large arteriovenous malformation (AVM) between the inferior mesenteric artery and vein in early (arterial) contrast window. 


\section{Learning points}

- Arteriovenous malformations (AVMs) are a rare cause of portal hypertension but should be sought, especially in the presence of a high-gradient ascites with a negative diagnostic work up of intrinsic hepatic disease.

- The diagnosis can be challenging, particularly if traditional locations are not involved (eg, splenic artery/vein).

- Inferior mesenteric AVM embolisation may be an alternative treatment in patients with a high operative risk, after weighing the risk of mesenteric ischaemia.
Competing interests None declared.

Patient consent Obtained.

Provenance and peer review Not commissioned; externally peer reviewed.

\section{REFERENCES}

1 Capuano G, Pomponi D, laccarino V, et al. An unusual case of ascitis. Dig Liver Dis 2004;36:628-31.

2 Baranda J, Pontes JM, Portela F, et al. Mesenteric arteriovenous fistula causing portal hypertension and bleeding duodenal varices. Eur J Gastroenterol Hepatol 1996;8:1223-5

Copyright 2015 BMJ Publishing Group. All rights reserved. For permission to reuse any of this content visit http://group.bmj.com/group/rights-licensing/permissions.

BMJ Case Report Fellows may re-use this article for personal use and teaching without any further permission.

Become a Fellow of BMJ Case Reports today and you can:

- Submit as many cases as you like

- Enjoy fast sympathetic peer review and rapid publication of accepted articles

- Access all the published articles

- Re-use any of the published material for personal use and teaching without further permission

For information on Institutional Fellowships contact consortiasales@bmjgroup.com

Visit casereports.bmj.com for more articles like this and to become a Fellow 